\title{
Water Hardness Removal Using Wheat Straw and Rice Husk Ash Properties
}

\author{
Hari Lal Kharel ${ }^{1 *}$, Ram Kumar Sharma ${ }^{1}, \&$ Tanka Prasad Kandel ${ }^{2}$ \\ ${ }^{1}$ Department of Civil Engineering, Institute of Engineering, Tribhuvan University, Lalitpur, Nepal \\ ${ }^{2}$ Department of Engineering, Aarhus University, P.O. Box 50, DK-8830, Tjele, Denmark
}

KEYWORDS

Indigenous technology; softening; tap water; water hardness; water sample

"CorRespondence

Tel: +977 15540555 , Fax: + 97715524344

E-mail: eng.civil6476@gmail.com

ARTicLe History

Received 16 March 2016

Revised 08 June 2016

Accepted 18 June 2016

ACADEMIC EDITOR

Gan B. Bajracharya

\section{Abstract}

This study examined potential of using wheat straw ash (WSA) and rice husk ash (RHA) to remove hardness of natural and hardness enriched synthetic water samples. Eight water samples (both natural and synthetic) with hardness ranging from 236 to $580 \mathrm{mg} / \mathrm{l}$ were treated with 10 different doses of WSA and RHA ranging from 2.5 to $25 \mathrm{~g}$ ash $\mathrm{l}^{-1}$ at regular increment of $2.5 \mathrm{~g}$ and one sample was included as control (no ash addition). Water hardness, hardness removal efficiency and $\mathrm{pH}$ changes of the treated water samples were measured. Hardness removal efficiency and $\mathrm{pH}$ of water increased with increasing doses of ash. Maximum removal was achieved at $17.5 \mathrm{~g} / \mathrm{l}$ and 22.5 $\mathrm{g} / \mathrm{l}$ for WSA and RHA, respectively, and further ash addition did not change the hardness. Maximum removal efficiency of WSA was $81 \%$ (i.e. $67 \mathrm{mg} / \mathrm{g}$ ) and RHA was $58 \%$ (i.e. $44 \mathrm{mg} / \mathrm{g}$ ). Higher hardness removal efficiency of WSA was due to presence of higher concentrations of alkali metal oxides. As similar to removal efficiency, WSA also increased $\mathrm{pH}$ of water samples relative to RHA. Maximum pH of 11.2 and 10.2 was respectively for WHA and RSA at the highest dose of ash $(25 \mathrm{~g} / \mathrm{l})$. The results thus indicate that locally available ashes from agricultural sources may be useful in hardness removal process, however, softened cannot be used as drinking water due to the high level of alkalinity.

\section{Introduction}

Presence of dissolved divalent ions, mainly calcium $\left(\mathrm{Ca}^{2+}\right)$ and magnesium $\left(\mathrm{Mg}^{2+}\right)$ acquired through contact with rocks and sediments in the environment, contribute water hardness (Brastad and He 2013). Hard water reduces the cleansing power of soap and thus can affect everyday household works such as laundering, bathing and dishwashing (Suzuki et al. 2002). When hard water is heated, lime scale deposits are formed, which can disrupt the operation of water using appliances as it produces noticeable deposit of precipitates (e.g. insoluble metals, soaps or salts). Hard water also produces scale in hot water lines which may reduce and clog water flow and thus frequent replacement is required (Suzuki et al. 2002). The scale buildup may also reduce the efficiency and performance of water pumps.

Groundwater in different parts of Nepal is contaminated with $\mathrm{Ca}^{2+}$ and $\mathrm{Mg}^{2+}$, which have contributed for high level of water hardness (Tamrakar and Shakya 2013; Shrestha and Shrestha 2011). Out of 270 water samples collected and analyzed from different intake sources, 60,20 and $10 \%$ of well, stream and spring water samples respectively had hardness above $180 \mathrm{mg} / \mathrm{l}$ (Tamrakar and Shakya 2013). Shrestha and Shrestha (2011) also found that $50 \%$ of water samples collected from wells in Kathmandu had water hardness greater than $180 \mathrm{mg} / \mathrm{l}$. Like wisely, Pant (2011) reported that groundwater collected from Kathmandu valley contained hardness as high as $800 \mathrm{mg} / \mathrm{l}$ (average $220-250 \mathrm{mg} / \mathrm{l}$ ).

Various advanced technologies are available to remove water hardness such as chemical precipitation, ionexchange, membrane separation, electro coagulation, solvent extraction, reduction, reverse osmosis (Hell et al. 1998; Schaep et al. 1998; Malakootianet al. 2010). However, such advanced technologies and materials are not easily accessible and affordable for small scale household level treatments in Nepal. Usage of ashes obtained by burning agricultural waste can be an option as ash contains potassium oxide and other metal oxides, and it can remove hardness making water alkaline (Demeyer et al. 2001) that provides a favorable condition for Ca2+ and Mg2+ precipitation (Xie et al. 2015). In Nepal, rice husk ash is the most easily available agricultural ashes as rice-mills mostly use rice husk as an energy source. People in Nepal have been traditionally using ash for washing clothes and cleaning utensils. Previous studies have shown that ash from various sources can be used for removal of heavy metals from wastewaters (Bhatnagar and Sillanpää 2010; Prasad et al. 2011). This study was designed to further understand efficacy and usefulness of ash derived from rice husk and wheat straw to remove $\mathrm{Ca}^{2+}$ and $\mathrm{Mg}^{2+}$ ions in water solution. Rice husk ash and wheat straw ash were selected as they are easily available as agricultural waste in Nepal, and contain different concentrations of potassium and other alkali metals.

\section{Materials and Methods \\ 2.1. Collection of raw materials for ash and its properties}

Wheat (Triticum aestivum cv Bhrikuti) straw was collected from a local field in Kathmandu and rice (Oryza sativa cv Loktantra) husk was collected from a rice mill. They were burned separately in a muffle furnace at $600^{\circ} \mathrm{C}$ until a constant weight of ash obtained. The ash content in wheat straw and rice husk were $10.4 \%$ and $19.5 \%$ of dry matter, respectively. Concentrations of sodium, potassium, calcium and magnesium in the ash were determined by atomic absorption spectrophometer (AAS) using acid digestion method. Concentrations of these elements in both ash types 
are presented in Table 1.

Table 1. Concentrations of metal elements $(\mathrm{g} / \mathrm{kg})$ in ashes

\begin{tabular}{llc}
\hline Element & $\begin{array}{l}\text { Rice husk ash } \\
(\mathrm{RHA})(\mathrm{g} / \mathrm{kg})\end{array}$ & $\begin{array}{l}\text { Wheat straw ash } \\
(\text { WSA })(\mathrm{g} / \mathrm{kg})\end{array}$ \\
\hline Sodium & 0.08 & 0.68 \\
Potassium & 9.3 & 32.2 \\
Calcium & 2.1 & 4.6 \\
Magnesium & 5.7 & 16.4 \\
\hline
\end{tabular}

Table 2. Characteristics and sampling locations of water samples Sample Description of the sample Initial Initial hardness $\mathrm{pH}$ $(\mathrm{mg} / \mathrm{l})$

$\begin{array}{llll} & \text { Well water of Tripureswor, Kathmandu } & 306 & 7.47 \\ 2 & \text { Tap water of Pulchowk campus, Lalitpur } & 236 & 7.60 \\ 3 & 400 & 6.48 \\ 4 & \text { Synthetic water of } \mathrm{Ca}^{2+} & 340 & 6.22 \\ 5 & \text { Synthetic water } \mathrm{Mg}^{2+} & 370 & 6.35 \\ 6 & 580 & 6.50 \\ \text { Synthetic water of combined } \mathrm{Ca}^{2+} \text { and } \mathrm{Mg}^{2+} & 520 & 6.25 \\ \text { Synthetic water of } \mathrm{Ca}^{2+} & \mathrm{Mg}^{2+} & 550 & 6.36\end{array}$

\subsection{Preparation of water samples}

The experiment included 2 groundwater and 6 artificially hardness enriched synthetic water samples. Sources and properties of the water samples used in this study are presented in Table 2. Synthetic water samples 3, 4 and 5 were prepared to make initial hardness $<500 \mathrm{mg} / \mathrm{l}$, which is normally found in water in Kathmandu. Water samples 6, 7 and 8 were prepared to make initial hardness $>500 \mathrm{mg} / \mathrm{l}$ as $\mathrm{Ca}^{2+}, \mathrm{Mg}^{2+}$ and $\mathrm{Ca}^{2+}+\mathrm{Mg}^{2+}$ hardness, respectively. The stock solutions for synthetic $\mathrm{Ca}^{2+}$ and $\mathrm{Mg}^{2+}$ hard water were prepared by adding $0.52 \mathrm{~g}$ of hydrated calcium chloride $\left(\mathrm{CaCl}_{2} .2 \mathrm{H}_{2} \mathrm{O}\right)$ and $0.82 \mathrm{~g}$ of hydrated magnesium sulphate $\left(\mathrm{MgSO}_{4} .7 \mathrm{H}_{2} \mathrm{O}\right)$ to $1 \mathrm{l}$ of distilled water, respectively. Both stock solutions contained $\mathrm{Ca}^{2+}$ and $\mathrm{Mg}^{2+}$ hardness of about $400 \mathrm{mg} / \mathrm{l}$.

\subsection{Hardness removal experiment}

For each analysis, $200 \mathrm{ml}$ of water sample was put into a $500 \mathrm{ml}$ beaker with a paddle jar to mix ash in water. The mixing speed was set at $100 \mathrm{rpm}$ using a portable electronic tachometer. Thereafter, ashes were added and followed by stirring for $10 \mathrm{~min}$. The residual hardness in treated water was measured using standard methods (APHA 1992) after one hour of settling time. Light flocks were formed in the mixture, which were filtered prior to water hardness and $\mathrm{pH}$ measurements.

All 8 types of water samples (Table 2) were treated with 10 different doses (2.5-25.0 $\mathrm{g}$ ash $\mathrm{l}^{-1}$ water at regular increment of $2.5 \mathrm{~g}$ ) of both ash types (wheat straw ash and rich husk ash, referred as WSA and RHA, respectively hereafter). Also, each type water sample was included as control (no ash addition).

Water hardness was measured using ethylene diamine tetraacetic acid (EDTA) method (Clesceri et al. 1998). In brief, total hardness was measured by titrating the water sample against EDTA or its sodium salt so as to form a stable complex ion with $\mathrm{Ca}^{2+}$ or $\mathrm{Mg}^{2+}$ ions in water. In the titration, Eriochrome Black $\mathrm{T}$ was used as an indicator to confirm all ions contributing for hardness were complexed. At first, 50 $\mathrm{ml}$ of hard water was taken in a $250 \mathrm{ml}$ titration flask, and then $2 \mathrm{ml}$ of $\mathrm{NH}_{3-} \mathrm{NH}_{4} \mathrm{Cl}$ buffer and three drops of Eriochrome Black $\mathrm{T}$ indicator were added, which changed the color of solution to wine red. The standard M/100 EDTA solution was titrated against water samples running from the burette until the color was changed from wine red to blue. The titration was repeated until two concurrent readings were obtained. Hardness was measured when all ions were complexed. Also, $\mathrm{pH}$ of the filtrates was measured using Chemiline digital $\mathrm{pH}$ meter (The Science House, Chennai, India).

\section{Results and Discussion}

The residual hardness decreased when treated with WSA and RHA (Fig. 1). In all water samples, maximum removal was achieved with lower dose of WSA (around 17.5-20.0 g/l) than RHA ( $\sim 22.5 \mathrm{~g} / \mathrm{l})$. Removal efficiency of WSA was always higher than RHA (Fig. 2). On average, maximum removal efficiency of WSA was 76\% (range 69-81\%), whereas it was only $55 \%$ for RHA (range 49-58\%). Maximum hardness removal efficiency of tap water (sample 2) with WSA (68\%) was considerably lower than average efficiency achieved for other water samples (81\%) with same ash type, which may be due to lower initial hardness of the sample (Table 2). The higher removal efficiency of WSA than RHA may be due to higher concentrations of potassium and other oxides present in the ash (Table 1). The results clearly indicate that both ash types have potentials to use as water softening materials. However, the results contradicted with the findings from Prasad et al. (2011) who reported that fly ash obtained from burning of coal increased total hardness of the mine water. The contrasting results might be related to different sources of ash, as the fly ash used in Prasad et al. (2011) study contained much lesser concentration of $\mathrm{K}(1.0 \%)$ compared to the concentrations $\mathrm{K}$ in RHA (9.3\%) and WSA (32.2\%) used this study (Table 1). Prasad et al. (2011), however, found that zeolite prepared from fly ash decreased hardness with increasing concentrations from 5 to $40 \mathrm{~g} / \mathrm{l}$. Prasad et al. (2011) also reported that zeolite rapidly removed hardness for the first but slowed down after $30 \mathrm{~min}$ and reached to steady state within $4 \mathrm{hrs}$. As contact time is an important aspect to remove hardness with adsorption method, further studies are needed to find saturation of the ion exchange capacity of different ash types.

For all water samples, $\mathrm{pH}$ increased with increased doses of ash (Fig. 3). Maximum pH of 11.2 and 10.2 were reached respectively for WHA and RSA at the highest dose of ash $(25$ $\mathrm{g} / \mathrm{l})$. Generally, large increase of $\mathrm{pH}$ of synthetic water samples was observed even at small doses of ash additions, which reached to saturation at higher doses. Such increase was also observed for natural water samples, but increasing rate was more gradual than synthetic water samples. In agreement with removal efficiency, WSA treated water samples had consistently higher $\mathrm{pH}$ than RHA treated samples.

Demeyer et al. (2001) reviewed $\mathrm{pH}$ of ashes from different sources and found a range from 8.9 to 13.19 (extracted in water). Such high alkaline nature of ash may have contributed for increased $\mathrm{pH}$. Oxides in ash are hydrated in water solutions to form hydroxides, which can later react with $\mathrm{CO}_{2}$ in order to form carbonates ions $\left(\mathrm{CO}_{3}-2\right)$ that contribute to such a rapid pH increase (Meiwes 1995; Eriksson 1998). The metal oxide concentrations in WSA were considerably higher than RHA (Table 1), and therefore, WSA might have been more efficient than RHA to increase water $\mathrm{pH}$. The rapid increase in $\mathrm{pH}$ however decreased the removal efficiency as maximal $\mathrm{Ca}$ and $\mathrm{Mg}$ adsorption capacity may be achieved in neutral pH (Sephehr et al. 2013). Although both ash types were effective to remove water hardness, results in this study suggest that water softening by the use of agricultural ash 


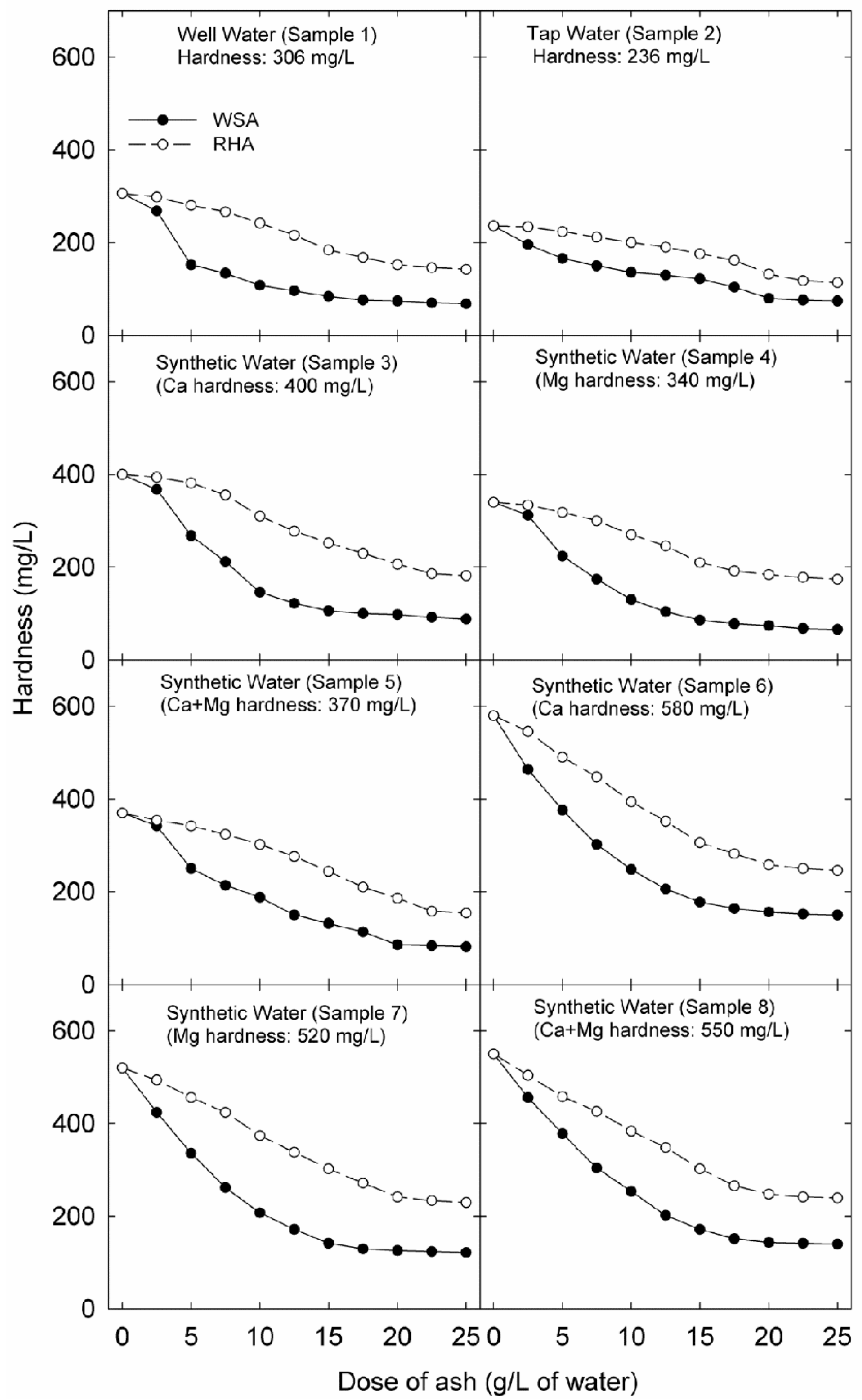

Fig. 1. Removal of total hardness from different water samples using different doses of wheat straw ash (WSA) and rice husk ash (RHA). Description about the water samples used is presented in Table 2. 


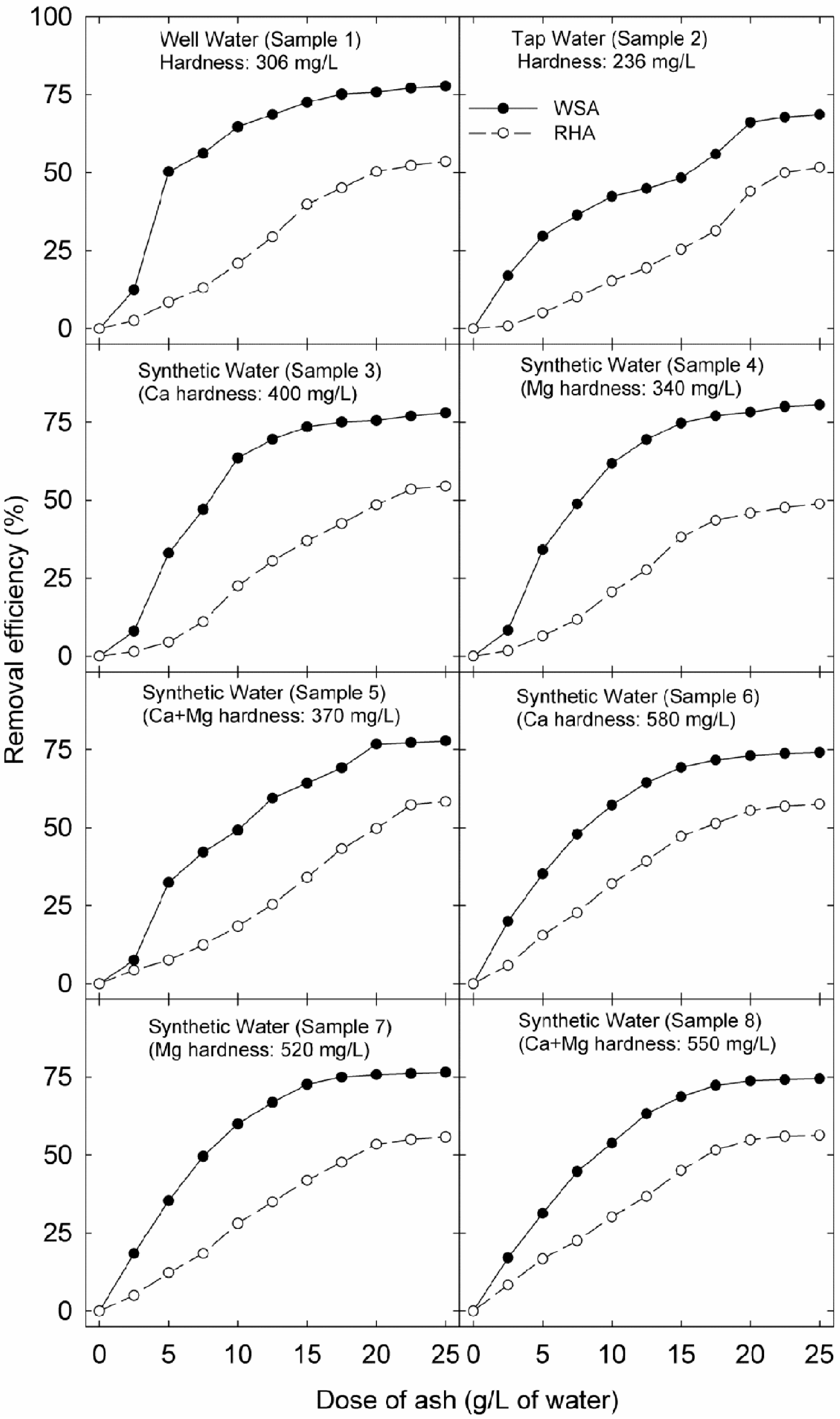


may not be suitable option for drinking purpose due to the high level of alkalinity in the treated water. However, this simple water softening method can be used for other usages, such as cleaning and laundering, where hard water is a major problem.

\section{Conclusion}

In this study, we compared wheat straw ash (WSA) and rice husk ash (RHA) for their hardness removal efficiency from water. Two water samples from natural sources and 6 synthetic water samples, with hardness ranging from 236 to $580 \mathrm{mg} / \mathrm{l}$ were included. Each water sample was treated with 10 different doses of both types of ashes ranging from 2.5 to $25 \mathrm{~g}$ ash $\mathrm{l}^{-1}$. Across all studied water samples, WSA showed higher hardness removal efficiency (average 76\%) than RHA (average $55 \%$ ) as the hardness removal reached saturation at lower dose $(17.5-20.0 \mathrm{~g} / \mathrm{l})$ of WSA addition than RHA (22.5 g/l). Although both ash sources were effective for hardness removal, it also created undesired consequence as $\mathrm{pH}$ of water samples increased even at small doses of ash addition which reached up to 11.2 and 10.2 for WSA and RHA treated samples, respectively at the highest dose. Thus, the results suggest that ash treatment is not useful for softening of drinking water but the technique can be used for other usages which require soft water.

\section{References}

APHA. 1992. Standard methods for the examination of water and wastewater. Eighteenth edition. American Public Health Association, Washington, DC.

Bhatnagar, A., and M. Sillanpää. 2010. Utilization of agro-industrial and municipal waste materials as potential adsorbents for water treatment - A review. Chemical Engineering Journal 157:277-296.

Brastad, K. S., and Z. He. 2013. Water softening using microbial desalination cell technology. Desalination 309:32-37.

Clesceri, L. S., A. E. Greenberg, and A.D. Eaton, editors. 1998. Standard methods for the examination of water and wastewater. Twenty edition. American Public Health Association, American Water Works Association, Water Environmental Federation, Washington, DC.

Demeyer, A., J. V. Nkana, and M. G. Verloo. 2001. Characteristics of wood ash and influence on soil properties and nutrient uptake: an overview. Bioresource Technology 77:287-295.
Eriksson, J. 1998. Dissolution of hardened wood ashes in forest soils: studies in a column experiment. Scandinavian Journal of Forest Research 2:23-32.

Hell, F., J. Lahnsteiner, H. Frischherz, and G. Baumgartner. 1998. Experience with full-scale electrodialysis for nitrate and hardness removal. Desalination 117:173-180.

Malakootian, M., H. J. Mansoorian, and M. Moosazadeh. 2010. Performance evaluation of electrocoagulation process using iron-rod electrodes for removing hardness from drinking water. Desalination 255:67-71.

Meiwes, K. J.1995. Application of lime and wood ash to decrease acidification of forest soils. Water Air and Soil Pollution 85:143152.

Pant, B. R. 2011. Ground water quality in the Kathmandu valley of Nepal. Environmental Monitoring and Assessment 178:477-485.

Prasad, B., K. Sangita, and B. K. Tewary. 2011. Reducing the hardness of mine water using transformed fly ash. Mine Water Environment 30:61-66.

Schaep, J., B. Van der Bruggen, S. Uytterhoeven, R. Croux, C. Vandecasteele, D. Wilms, E. Van Houtte, and F. Vanlerberghe. 1998. Removal of hardness from groundwater by nanofiltration. Desalination 119:295-301.

Sepehr, M. N., M. Zarrabi, H. Kazemian, A. Amrane, K. Yaghmaian, and H. R. Ghaffari. 2013. Removal of hardness agents, calcium and magnesium, by natural and alkaline modified pumice stones in single and binary systems. Applied Surface Science 274:295-305.

Shrestha, I. L., and S. L. Shrestha. 2011. Statistical models and water quality characterization of source waters in Nepal. Nepal Journal of Science and Technology 12:260-267.

Suzuki, K., Y. Tanaka, T. Osada, and M. Waki. 2002. Removal of phosphate, magnesium and calcium from swine wastewater through crystallization enhanced by aeration. Water Research 36:2991-2998.

Tamrakar, C. S., and P. R. Shakya. 2013. Physico-chemical assessment of deep groundwater quality of various sites of Kathmandu Metropolitan City, Nepal. Research Journal of Chemical Sciences 3:78-82.

Xie, H., T. Liu, Z. Hou, Y. Wang, J. Wang, L. Tang, W. Jiang, and Y. He. 2015. Using electrochemical process to mineralize $\mathrm{CO}_{2}$ and separate $\mathrm{Ca}+/ \mathrm{Mg} 2+$ ions from hard water to produce high value-added carbonates. Environmental Earth Sciences 73:68816890. 